\title{
Challenge for 2022: Innovating Despite Uncertainty
}

\author{
Daniel Forbes (University of Minnesota, Carlson School of Management) \\ Jon Eckhardt (University of Wisconsin-Madison)
}

KEYWORDS: Innovation, Product Development, crisis management.

The year-end is traditionally a time for setting new goals for the coming year, but if we've learned anything from 2020 and 2021 it's that our best-laid plans must be flexible. The continued uncertainty over the effect of the new Omicron variant of Covid-19 --- and the continued labor and supply chain shortages -- has put many entrepreneurs and small business owners on edge and hesitate to commit.

Yet judging from our best-read articles over the past year, innovators still want to innovate. EIX site visitors gravitated towards our articles and videos that showed them them not only how to survive bad times, but also how to create new products and lay the groundwork for future growth. Our best-read articles overwhelmingly fell into two themes: survival, and bringing a great idea from concept to market. So to get you ready for 2022, here are some of our articles with those themes that attracted the most readers over the past year.

\section{Dealing with Crisis}

How to Care for Your Team During a Crisis (https://eiexchange.com/content/how-to-care-for-yourteam-during-a-crisis)

Because of labor shortages, this advice from Texas Tech professors James Wetherbe and Theodore Waldron is more relevant than ever. It has attracted more than 285,000 site visitors.

\section{Which Innovations Should You Keep When the Crisis is Over?(https://eiexchange.com/content/which- innovations-should-you-keep-when-the-crisis-is-over) \\ Not all innovations made out of necessity will last. But smart companies will identify the ones worth keeping and make them better.}

\section{Working from Home: Tips for Employees and Business Owners}

(https://eiexchange.com/content/which-innovations- should-you-keep-when-the-crisis-is-over)

What started out as a reaction to the pandemic has become a lasting thing. How to make it work.

Take a CLEAN Look at Your Business PostCovid-19(https://eiexchange.com/content/take-a-cleanlook-at-your-business-post-covid19)

Emerging from the pandemic will provide small business owners a clean slate upon which to reinvent their companies.

Building a Stronger Supply Chain: Lessons From the Crisis(https://eiexchange.com/content/building-astronger-supply-chain-lessons-from-the-crisis)

This article on this hot topic from David Johnston, Director of the George Weston Ltd. Centre for Sustainable Supply Chains at York University, amassed more than 10,000 views in its first few days on our site.

\section{Innovation}

Why Inventors Should Embrace Unequal Partnerships(https://eiexchange.com/content/285-whyinventors-should-embrace-unequal-partnership)

In our top-read article of all time (306,000 views and counting), "Modern-Day Thomas Edison" Dean Kamen talks frankly about the need to partner with big companies. The payoff is smaller piece of a much bigger pie.

Learn From Leaders: Developing an Idea (https://eiexchange.com/content/learn-from-leadersdeveloping-an-idea)

In our second most-popular article and video, attracting more than 170,000 visitors over the past year, the founders of Best Buy, MinuteClinic, LegalZoom and other great companies talk about how they built them. 


\section{Design Thinking Makes Great Ideas Valuable}

(https://eiexchange.com/content/311-design-thinkingmakes-great-ideas-viable)

Design Thinking (often referred to as "Human-Centered Design") is a design/development process that helps you understand your potential customers' real wants and needs - at a deep, often emotional level. This is an exercise that can be done with two or more people, inside or outside a classroom.

\section{"Becoming DaVinci" Exercise Ignites the Inventor} Spirit(https://eiexchange.com/content/becoming-davinci-exercise-ignites-the-inventor-spirit)

Students -- and for that matter, practicing entrepreneurs -- often have a hard time understanding the difference between an invention and an innovation and, likewise, the difference between incremental and disruptive innovation. This exercise helps them delve into the mind of an inventor.

The 5 Mortal Sins of New Product Development (https://eiexchange.com/content/the-5-mortal-sins-ofnew-product-development)

Sometimes an innovator or new company has an idea for a product that seems to have blockbuster potential -only to fizzle and flop. Why does this happen?

For the Best Customer Data, Look Beyond the Market(https://eiexchange.com/content/262-for-thebest-customer-data-look-beyond-the-marke)

By studying passionate "early adopters," entrepreneurs can glean information that can be used to identify the potential market acceptance of a more complete version of the product.

\section{Delivering the Goods: An Interview with Best Buy and EIX Founder Dick Schulze} (https://eiexchange.com/content/6-delivering-the-goodsan-interview-with-best-buy)

The onetime newspaper delivery carrier talks about the genesis of the idea for Best Buy -- in the rubble of a former business wrecked by a tornado. Timeless wisdom especially now. 